\title{
ANALISIS OPTIMASI KADAR VITAMIN C DARI FILTRAT BUAH NANAS (Ananas comosus L Merr) MENGGUNAKAN SISTEM EVAPORATOR VACUUM
}

\author{
Qurrotun A'yuni Khoirun Nisa' \\ PSD III Teknik Kimia, Sekolah Vokasi, UniversitasDiponegoro \\ Jl. Prof. Sudarto, SH, Tembalang, Semarang 50275 \\ *Email: ayuniqurrotun13@gmail.com
}

\begin{abstract}
Abstrak
Riset ini bertujuan untuk mengembangkan skema proses evaporasi untuk analisa kadar vitamin $C$. Target yang ingin dicapai berupa optimisasi parameter proses. Kajian dilakukan pada berbagai variabel,meliputi suhu $\left(40-60{ }^{\circ} \mathrm{C}\right)$, konsentrasi $(20-40 \mathrm{~g} / \mathrm{L})$, dan waktu (60 - 90 menit. Sedangkan variabel bergantungnya adalah viskositas, moisture content, dan kadar vitamin C. Penentuan variabel yang berpengaruh dapat menggunakan central composite rotatotional design (CCRD). Percobaan menunjukkan bahwa kondisi optimum pengaruh variabel evaporasi terhadap kadar vitamin $C$, diperoleh saat nilai kadar vitamin C lebih dari 0,00014\% dengan konsentrasi 34 - 36 g/L pada suhu 56 - 58 ${ }^{\circ}$ C selama 80 - 90 menit.
\end{abstract}

Kata kunci: evaporasi, nanas, vitamin C

\section{PENDAhUluan}

Nanas (Ananas comosus L. Merr) merupakan tanaman buah yang berasal dari Amerika tropis yaitu Brazil, Argentina dan Peru. Tanaman nenas telah tersebar ke seluruh penjuru dunia, terutama di sekitar daerah khatulistiwa yaitu antara $25^{\circ} \mathrm{LU}$ dan $25^{\circ} \mathrm{LS}$. Di Indonesia tanaman nenas sangat terkenal dan banyak dibudidayakan di tegalan dari dataran rendah sampai ke dataran tinggi. Daerah penghasil nenas di Indonesia yang terkenal adalah Subang, Bogor, Riau, Palembang dan Blitar (Safitri, 2015). Nanas banyak diminati oleh masyarakat, akan tetapi nanas memiliki waktu panen yang cukup lama. Panen buah nanas dilakukan setelah nanas berumur 12-24 bulan, tergantung dari jenis bibit yang digunakan. Bibit yang berasal dari mahkota bunga berbuah pada umur 24 bulan, hingga panen buah setelah berumur 24 bulan. Tanaman yang berasal dari tunas batang dipanen setelah umur 18 bulan, sedangkan tunas akar setelah berumur 12 bulan (Rocky, 2009).

Komponen utama penyusun buah nanas adalah Vitamin C sebesar $20 \mathrm{mg} / 100 \mathrm{~g}$ buah nanas (Pertamasari,2014). Masa panen buah sangat terbatas, oleh karena itu buah yang dipanen diolah menjadi jus buah, selai, dan buah kaleng. Jus buah biasanya terkonsentrasi untuk memperpanjang umur simpan mereka. Jus buah terkonsentrasi memiliki ketahanan yang lebih tinggi terhadap pertumbuhan mikroba daripada yang tidak terkonsentrasi karena penurunan aktivitas air. Proses konsentrasi juga mengurangi volume jus buah, dan akibatnya menurunkan biaya transportasi, penyimpanan, dan pengemasan (Cassano dkk., 2003; Onsekizoglu dkk., 2010). Namun, pembentukan komponen yang tidak diinginkan dan kehilangan karakteristik kualitas diidentifikasi dalam kasus metode evaporasi termal. Metode baru seperti konsentrasi membran dan konsentrasi beku telah diteliti sebagai metode konsentrasi alternatif. Tetapi dalam kasus ini, diteliti membutuhkan biaya operasional dan pemasangan yang tinggi selain masalah untuk mencapai nilai TSS tinggi dengan metode ini (Cassano dkk., 2007; Onsekizoglu, 2013; Ramteke dkk., 1993). Metode penguapan yang paling umum digunakan dalam industri adalah proses evaporasi vakum karena dalam kondisi tersebut suhu bias diatur sesuai dengan keinginan serta dalam kondisi vakum sehingga akan menjaga nutrisi / gizi produk tidak hilang atau rusak (Sabanci dkk., 2017).

Saat ini, studi pada subjek penguapan vakum dan metode dibantu pemanas dalam literatur masih terbatas. Gaily (1999) telah mendesain sistem evaporasi vakum ohm silinder untuk jus apel pinus. Demikian pula, Wang dan Chu (2003) membahas bahwa penguapan vakum dengan pemanasan bisa menguapkan lebih banyak uap air daripada proses konvensional dalam waktu yang sama. Penguapan pada jus nanas menggunakan evaporator dengan pemanas masih belum banyak diteliti karena kandungan gizi pada jus nanas tidak tahan terhadap suhu tinggi seperti enzim bromelin, protein, dan lain - 
lain. Lamanya waktu operasi pada sistem evaporator akan mempengaruhi banyaknya kadar air yang teruapkan (moisture content) sehingga dapat diketahui kondisi optimum operasi dalam proses evaporasi pada buah nanas.

\section{METODOLOGI}

\subsection{Bahan}

Bahan penelitian berupa buah nanas, dan bahan-bahan kimia yang diperlukan untuk proses evaporasi. Bahan untuk analisa produk meliputi asam askorbat untuk analisis vitamin C. Buah nanas jenis sunpride dibeli dari supermarket Superindo, sedangkan untuk asam askorbat diperoleh dari Toko Multi Kimia Raya Semarang dan aquades didapatkan dari laboratorium Operasi Teknik Kimia PSDIII Teknik Kimia Sekolah Vokasi UNDIP.

\subsection{Alat Penelitian}

Alat utama yang akan digunakan dalam penelitian adalah agitated thin film evaporator. Rangkaian alat agitated thin film evaporator yang akan digunakan terdiri dari sebuah tangki evaporator 10 liter yang dilengkapi dengan pemanas band heater, indikator temperatur, pengaduk dan kondensor. Bahan dialirkan masuk kedalam evaporator bagian tabung dalam menggunakan pompa. Bahan masuk dari atas dan keluar dari bawah, yang menjadikan aliran pemanas dan aliran bahan menjadi searah atau cocurent. Pada sumbu tabung terdapat batang yang dapat diputar, yang dilengkapi dengan sirip-sirip. Pada Agitated Thin-Film Evaporator, saat batang berputar, cairan bergerak kebawah dan akan terlempar ketepi tabung (bagian panas) karena putaran sirip. Cairan ditepi tabung akan terpental kembali ketengah tabung. Ketika bahan sudah sampai di ujung bawah evaporator, bahan hasil pemekatan tersebut akan diserap dengan pompa untuk dialirkan menuju tangki umpan kembali. Sedangkan alat yang akan digunakan untuk uji kadar vitamin $\mathrm{C}$ adalah spektrofotometer sinar tampak. Alat yang digunakan untuk analisa viskositas adalah piknometer dan viskosimeter Ostwald. Sedangkan untuk uji moisture content adalah cawan petri, kertas saring dan oven.

\subsection{Prosedur Persiapan Bahan}

Sebelum proses evaporasi, dilakukan proses ekstraksi buah nanas terlebih dahulu dengan menggunakan blender. Buah nanas yang telah di potong kecil-kecil dan diblender kemudian dipisahkan antara filtrat dan ekstraknya. Filtrat yang telah terpisahkan ditambahkan aquadest sebanyak 4,5 liter untuk di evaporasi. Penentuan variabel pada praktikum menggunakan metode Response Surface Methodology (RSM) standard design factor/blok/run: 3/1/16. Langkah pertama yang dilakukan yaitu menentukan summary for variable yang terdiri dari suhu dengan nilai terendah yaitu $40^{\circ} \mathrm{C}$; nilai tengah yaitu $50^{\circ} \mathrm{C}$ dan nilai tertinggi yaitu $60^{\circ} \mathrm{C}$. Langkah kedua menentukan nilai konsentrasi dengan nilai terendah $20 \mathrm{~g} / \mathrm{L}$; nilai tengah yaitu $\mathrm{g} / \mathrm{L}$ dan nilai tertinggi yaitu $60 \mathrm{~g} / \mathrm{L}$. Langkah ketiga yaitu menentukan nilai waktu dengan nilai terendah yaitu 30 menit; nilai tengah yaitu 60 menit dan nilai tertinggi yaitu 90 menit. Pada praktikum ini menggunakan perhitungan alpha for orthogonality sebesar 1,2872.

\subsection{Studi Optimisasi Proses}

Proses optimasi dilakukan dengan menerapkan Central Composite Design (CCD). Dasar dari proses optimasi ini meliputi tiga tahap, yaitu melakukan percobaan yang dirancang secara statistik, memperkirakan koefisien dalam model matematika dan memprediksi respon dengan memeriksa kesesuaian model (Sridevi dkk., 2011; Box dan Hunter, 1957; Box dkk., 1978). Selanjutnya untuk model orde II, biasanya terdapat kelengkungan dan digunakan model polinomial orde kedua yang fungsinya kuadratik:

$$
Y=R_{0}+\sum_{i=1}^{k} R_{i} X_{i}+\sum_{i=1}^{k} R_{i i} X_{i}^{2}+\sum_{i=1, i<j}^{k-1} \sum_{j=2}^{k} R_{i j} X_{i} X_{j}+\varepsilon
$$

Rancangan eksperimen orde II yang digunakan adalah rancangan faktorial 3k (Three Level Factorial Design), yang sesuai untuk masalah optimasi. Dimana $\mathrm{Xi}, \mathrm{Xj}$ adalah variabel input yang mempengaruhi respon $\mathrm{Y}$; Ro, Ri, Rii dan Rij ( $\mathrm{i}=1-\mathrm{k}, \mathrm{j}=1-\mathrm{k}$ ) adalah parameter yang dikenal, dan $\varepsilon$ adalah kesalahan acak. Model orde kedua dirancang sehingga variansi $Y$ konstan untuk semua titik yang berjarak sama dari pusat desain. Kemudian dari model orde II ditentukan titik stasioner, karakteristik permukaan respon dan model optimasinya. Sebanyak 16 percobaan dilakukan untuk memperkirakan koefisien model menggunakan regresi linier berganda. Desain eksperimen yang digunakan untuk analisis menggunakan software Statistika versi 10.0. 
Tabel 1. Nilai variabel tetap pada berbagai tingkat percobaan

\begin{tabular}{llll}
\hline Run & Suhu $\left({ }^{\mathbf{0}} \mathbf{C}\right)$ & Konsentrasi $(\mathbf{g} / \mathbf{L})$ & Waktu $(\mathbf{m i n})$ \\
\hline 1 & $\mathbf{X}_{\mathbf{1}}$ & $\mathbf{X}_{\mathbf{2}}$ & $\mathbf{X}_{\mathbf{3}}$ \\
2 & 40 & 20 & 30 \\
3 & 40 & 20 & 90 \\
4 & 40 & 40 & 30 \\
5 & 40 & 40 & 90 \\
6 & 60 & 20 & 30 \\
7 & 60 & 20 & 90 \\
8 & 60 & 40 & 30 \\
9 & 60 & 40 & 90 \\
10 & 37.12 & 30 & 60 \\
11 & 62.87 & 30 & 60 \\
12 & 50 & 17.12 & 60 \\
13 & 50 & 42.87 & 60 \\
14 & 50 & 30 & 21.38 \\
15 & 50 & 30 & 98.62 \\
16 & 50 & 30 & 60 \\
\hline
\end{tabular}

\section{HASIL DAN PEMBAHASAN}

Optimasi proses dari hasil percobaan dapat dibuat response fitted surface (Gambar 1). Gambar 1(a) menunjukkan hubungan antara kadar vitamin C, konsentrasi dan waktu. Dengan menerapkan analisis regresi berganda pada data percobaan, diperoleh persamaan polinomial tingkat dua untuk mewakili perolehan kadar vitamin $\mathrm{C}$ sebagai berikut:

$\mathrm{Y}=0,00029352566300328$

$0,000000032615534355 \mathrm{X}_{2}+$

$0,000000139686450913 \mathrm{X}_{2}^{2}+$

$0,00000047537387514 \mathrm{X}_{3}+$

$0,000000014513605497 \mathrm{X}_{3}{ }^{2}-0,00000008375$

$\times 49,999375 \mathrm{X}_{2}-$

$0,000000027083333333 \times 49,999375 \mathrm{X}_{3}-$

$0,000000032083333333 \mathrm{X}_{2} \mathrm{X}_{3}$ -

0,00014839

Pada gambar 1(a) diketahui bahwa nilai kadar vitamin C optimum mencapai lebih dari 0,00014 $\%$ dicapai pada konsentrasi antara $34-36 \mathrm{~g} / \mathrm{L}$ dengan lama waktu antara 80 - 90 menit. Sedangkan, pada gambar 1(b) menunjukkan hubungan antara kadar vitamin $\mathrm{C}$, suhu dan konsentrasi. Dengan menerapkan analisis regresi berganda pada data percobaan, diperoleh persamaan polinomial tingkat dua untuk mewakili perolehan kadar vitamin $\mathrm{C}$ sebagai berikut:

$\mathrm{Y}=0,00029352566300328-$

$0,00001024808916873 X_{1}+$

$0,000000145607538856 \mathrm{X}_{1}^{2}-$

$0,000000032615534355 \mathrm{X}_{2}+$

$0,000000139686450913 X_{2}^{2}-0,00000008375$

$\mathrm{X}_{1} \mathrm{X}_{2}-0,000000027083333333 \times 60 \mathrm{X}_{1}-$

$0,000000032083333333 \times 60 \mathrm{X}_{2}+$

0,000080771

Pada gambar 1(b) diketahui bahwa nilai kadar vitamin C optimum mencapai lebih dari 0,00014 $\%$ dicapai pada suhu 56 - $58{ }^{\circ} \mathrm{C}$ dengan konsentrasi antara 34 - $36 \mathrm{~g} / \mathrm{L}$. Dalam Gambar 10(c) menunjukkan hubungan antara kadar vitamin C, suhu dan waktu. Dengan menerapkan analisis regresi berganda pada data percobaan, diperoleh persamaan polinomial tingkat dua untuk mewakili perolehan kadar vitamin $\mathrm{C}$ sebagai berikut:

$\mathrm{Y}=0,00029352566300328-$

$0,00001024808916873 X_{1}+$

$0,000000145607538856 X_{1}^{2}+$

$0,00000047537387514 \mathrm{X}_{3}+$

$0,000000014513605497 \mathrm{X}_{3}^{2}-0,00000008375 \times$ $29,999375 \mathrm{X}_{1}-0,000000027083333333 \mathrm{X}_{1} \mathrm{X}_{3}-$

$0,000000032083333333 \times 29,999375 \mathrm{X}_{3}+$

0,000124734 . 
Pada gambar 1(c) diketahui bahwa kadar vitamin C optimum mencapai lebih dari 0,00014 $\%$ dicapai pada suhu antara $56-58{ }^{\circ} \mathrm{C}$ dengan lama waktu antara $80-90$ menit. Sehingga, dapat disimpulkan bahwa kondisi optimum pengaruh variabel evaporasi terhadap kadar vitamin $\mathrm{C}$, diperoleh saat nilai kadar vitamin $\mathrm{C}$ lebih dari $0,00014 \%$ dengan konsentrasi $34-36$ g/L pada suhu $56-58{ }^{\circ} \mathrm{C}$ selama $80-90$ menit.

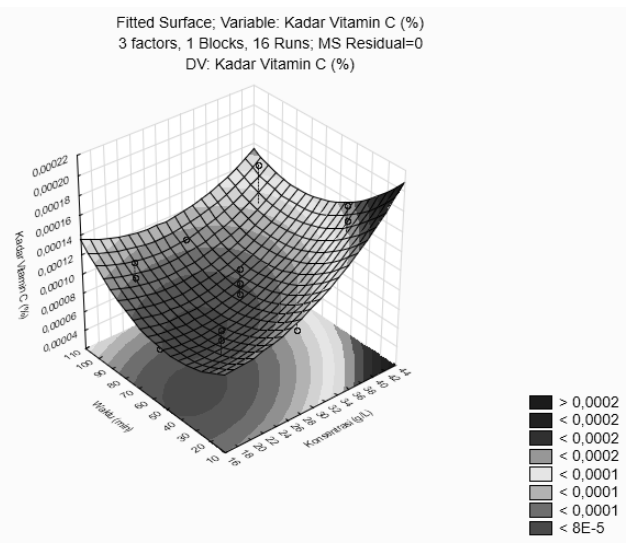

Hubungan waktu (min) dan konsentrasi $\left(\mathrm{g} / \mathrm{L}\right.$ ) terhadap vitamin $\mathrm{C}$ pada suhu $50^{\circ} \mathrm{C}$ (a)

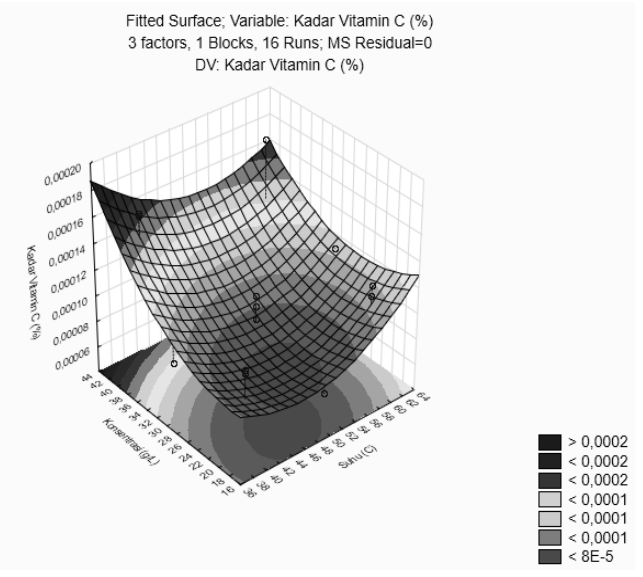

Hubungan waktu (min) dan konsentrasi $(\mathrm{g} / \mathrm{L})$ terhadap vitamin $\mathrm{C}$ pada waktu 60 menit (b)

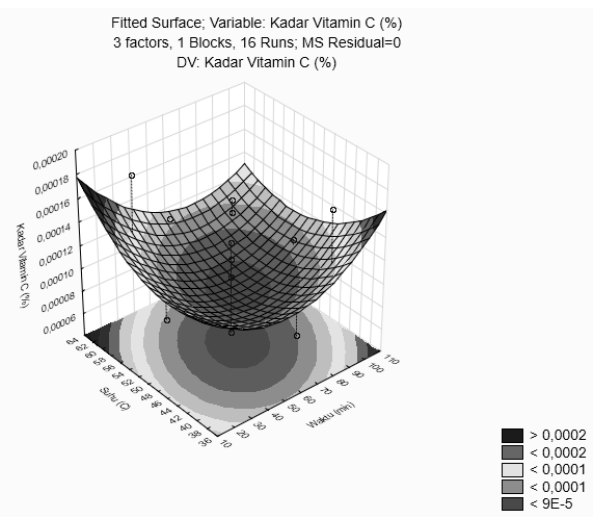

Hubungan Suhu (oC) dan waktu (min) terhadap vitamin C pada konsentrasi 30g/L (c)

Gambar 1. (a), (b), (c), Response fifted surface variabel lama waktu, suhu, dan evaporasi terhadap respon kadar vitamin $\mathrm{C}$

Optimasi proses untuk evaporasi jus buah nanas dilakukan melalui 16 percobaan menggunakan variabel bebas suhu, konsentrasi, dan waktu. Nilai test $\mathrm{t}$ menunjukkan nilai lebih besar dari nilai p. Keakuratan model ini dapat diketahui dari harga koefisien determinasi (R2). 
Nilai R2 memberikan ukuran seberapa banyak variabilitas dalam nilai-nilai respon yang diamati dapat dijelaskan oleh variabel percobaan dan interaksi mereka. Dari harga R2 ini dapat disimpulkan bahwa nilai yang diperkirakan dengan model mendekati nilai yang diperoleh dari hasil percobaan. Nilai R2 selalu berada di antara 0 dan 1 . Semakin dekat nilai R2 terhadap 1, menunjukkan bahwa model tersebut baik dalam memprediksi respon. Dalam hal ini, nilai koefisien determinasi $(\mathrm{R} 2=0.73277)$ menunjukkan bahwa 73,277 \% dari variabilitas dalam respon dapat dijelaskan oleh model (Tabel 2).

\section{Tabel 2. Data Estimasi Efek}

\begin{tabular}{|c|c|c|c|c|c|c|c|c|c|c|}
\hline \multirow[b]{2}{*}{ Factor } & \multicolumn{10}{|c|}{$\begin{array}{l}\text { Effect Estimates; Var..Kadar Vitamin C (\%); R-sqr=.73277; Adj: } 33193 \text { (HASIL RSM) } \\
3 \text { factors, } 1 \text { Blocks, } 16 \text { Runs; MS Residual=450.6103 } \\
\text { DV: Kadar Vitamin C (\%) }\end{array}$} \\
\hline & Effect & Std.Err. & $t(6)$ & $p$ & $\begin{array}{c}-95 . \% \\
\text { Cnf.Limt }\end{array}$ & $\begin{array}{c}+95 \% \\
\text { Cnf.Limt }\end{array}$ & Coeff. & $\begin{array}{l}\text { Std.Err. } \\
\text { Coeff. }\end{array}$ & $\begin{array}{c}-95 \% \% \\
\text { Cnf.Limt }\end{array}$ & $\begin{array}{c}+95 . \% \\
\text { Cnf.Limt }\end{array}$ \\
\hline Mean/Interc. & -5.1731 & 12.30160 & -0.42052 & 0.688750 & -35.2740 & 24.92786 & -5.1731 & 12.30160 & -35.2740 & 24.92786 \\
\hline (1)Suhu (C)(L) & -18.3563 & 12.62110 & -1.45442 & 0.196064 & -49.2391 & 12.52638 & -9.1782 & 6.31055 & -24.6195 & 6.26319 \\
\hline Suhu $(C)(Q)$ & 11.1003 & 18.11385 & 0.61281 & 0.562495 & -33.2227 & 55.42329 & 5.5502 & 9.05692 & -16.6113 & 27.71165 \\
\hline (2)Konsentrasi $(\mathrm{mg} / \mathrm{L})(\mathrm{L})$ & -18.3151 & 12.62110 & -1.45115 & 0.196935 & -49.1979 & 12.56760 & -9.1576 & 6.31055 & -24.5989 & 6.28380 \\
\hline Konsentrasi $(\mathrm{mg} / \mathrm{L})(\mathrm{Q})$ & 11.0991 & 18.11385 & 0.61274 & 0.562536 & -33.2239 & 55.42211 & 5.5496 & 9.05692 & -16.6119 & 27.71105 \\
\hline (3)Waktu (min)(L) & 18.3592 & 12.62158 & 1.45459 & 0.196019 & -12.5247 & 49.24310 & 9.1796 & 6.31079 & -6.2623 & 24.62155 \\
\hline Waktu $(\min )(Q)$ & 11.1180 & 18.11654 & 0.61369 & 0.561946 & -33.2116 & 55.44761 & 5.5590 & 9.05827 & -16.6058 & 27.72380 \\
\hline $1 \mathrm{~L}$ by $2 \mathrm{~L}$ & 25.9573 & 15.01017 & 1.72931 & 0.134483 & -10.7713 & 62.68581 & 12.9786 & 7.50508 & -5.3857 & 31.34291 \\
\hline $1 \mathrm{~L}$ by $3 \mathrm{~L}$ & -25.9903 & 15.01017 & -1.73151 & 0.134075 & -62.7188 & 10.73831 & -12.9951 & 7.50508 & -31.3594 & 5.36916 \\
\hline $2 \mathrm{~L}$ by $3 \mathrm{~L}$ & -25.9933 & 15.01017 & -1.73171 & 0.134038 & -62.7218 & 10.73531 & -12.9966 & 7.50508 & -31.3609 & 5.36766 \\
\hline
\end{tabular}

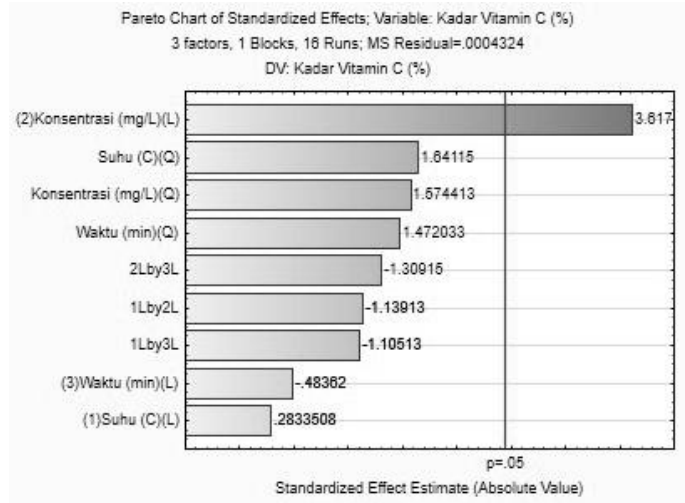

Gambar 2. Diagram pareto pengaruh variabel terhadap kadar vitamin C

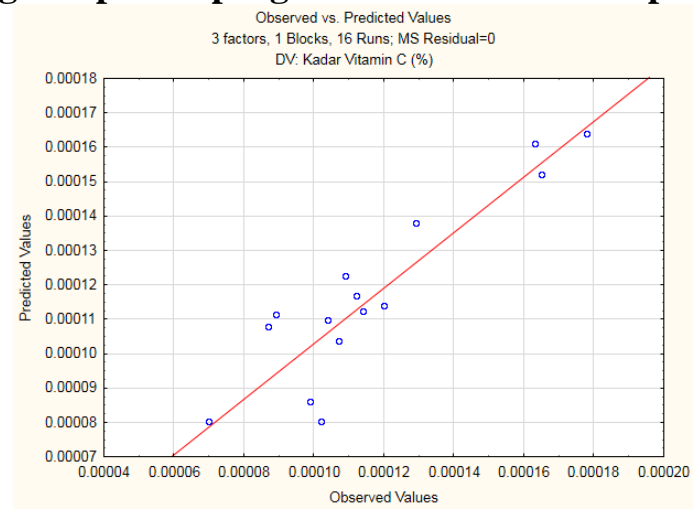

Gambar 3. Perbandingan data percobaan dan perkiraan kadar vitamin C 
Kedekatan nilai yang diperkirakan dengan model mendekati nilai yang diperoleh dari hasil percobaan disajikan pada Gambar 3. Nilai plot dalam grafik menunjukkan korelasi yang memuaskan antara nilai-nilai percobaan dan perkiraan (diperoleh dari Persamaan 1), karena penyimpangan antara nilai-nilai percobaan dan perkiraan mendekati garis linear. Koefiesien regresi dapat diperjelas dengan diagram pareto (Gambar 2) untuk setiap variabel. Dari blok diagram, tampak bahwa variabel bebas yang aling berpengaruh dalam proses evaporasi buah nanas adalah konsentrasi.

Tabel 3. Analisa varian model persamaan polinomial evaporasi jus buah nanas

\begin{tabular}{|c|c|c|c|c|c|c|}
\hline \multirow[b]{2}{*}{ Factor } & \multicolumn{6}{|c|}{$\begin{array}{l}\text { ANOVA; Var.:Kadar Vitamin C (\%); R-sqr=.8062; Adj:. } 51551 \text { (HASIL RSM) } \\
3 \text { factors, } 1 \text { Blocks, } 16 \text { Runs; MS Residual=.0004324 } \\
\text { DV: Kadar Vitamin C (\%) }\end{array}$} \\
\hline & SS & df & MS & $\mathrm{F}$ & $p$ & \\
\hline (1)Suhu (C)(L) & 0.000035 & 1 & 0.000035 & 0.08029 & 0.786431 & \\
\hline Suhu $(C)(Q)$ & $0.001165^{2}$ & 1 & 0.001165 & 2.69337 & 0.151875 & \\
\hline (2)Konsentrasi $(\mathrm{g} / \mathrm{L})(\mathrm{L})$ & 0.005658 & 1 & 0.005658 & 13.08359 & 0.011135 & \\
\hline Konsentrasi $(g / L)(Q)$ & 0.001072 & 1 & 0.001072 & 2.47878 & 0.166458 & \\
\hline (3)Waktu (min)(L) & 0.000101 & 1 & 0.000101 & 0.23389 & 0.645799 & \\
\hline Waktu (min)(Q) & 0.000937 & 1 & 0.000937 & 2.16688 & 0.191430 & \\
\hline $1 \mathrm{~L}$ by $2 \mathrm{~L}$ & 0.000561 & 1 & 0.000561 & 1.29762 & 0.298075 & \\
\hline $1 \mathrm{~L}$ by $3 \mathrm{~L}$ & 0.000528 & 1 & 0.000528 & 1.22131 & 0.311438 & \\
\hline $2 \mathrm{~L}$ by $3 \mathrm{~L}$ & 0.000741 & 1 & 0.000741 & 1.71388 & 0.238382 & \\
\hline Error & 0.002595 & 6 & 0.000432 & & & \\
\hline Total SS & 0.013388 & 15 & & & & \\
\hline
\end{tabular}

Hasil dari model respon permukaan tingkat kedua sesuai dalam bentuk Analysis of Variance (ANOVA) yang diberikan dalam Tabel 3. Hal ini diperlukan untuk menguji signifikansi dan kecukupan model. Fisher rasio varians, nilai F (= $\mathrm{S}^{2} / \mathrm{S}^{2}$ ), adalah ukuran statistik yang valid dari seberapa baik faktor menjelaskan variasi dalam data tentang mean. Semakin besar nilai $F$ semakin menunjukkan keseragaman, yang lebih pasti adalah bahwa faktor menjelaskan secara memadai variasi dalam data tentang mean, dan efek faktor yang diperkirakan adalah nyata. ANOVA dari model regresi menunjukkan bahwa model ini sangat signifikan, seperti terbukti dari nilai $\mathrm{F}$ dari tes Fisher $($ Fmodel $=24,969)$.

Tabel 4. Nilai prediksi kadar vitamin C optimum pada nilai kritis dari suhu, konsentrasi, dan waktu

\begin{tabular}{l|r|r|r|}
\multirow{2}{*}{} & \multicolumn{3}{|l}{$\begin{array}{l}\text { Critical values; Variable: Kadar Vitamin C (\%) (HASIL RSM fix) } \\
\text { Solution: minimum } \\
\text { Predicted value at solution: .0000739 }\end{array}$} \\
\cline { 2 - 4 } & $\begin{array}{l}\text { Observed } \\
\text { Minimum }\end{array}$ & $\begin{array}{c}\text { Critical } \\
\text { Values }\end{array}$ & $\begin{array}{c}\text { Observed } \\
\text { Maximum }\end{array}$ \\
\hline Factor & 37.12000 & 44.96122 & 62.87000 \\
\hline Suhu (C) & 17.12000 & 18.93554 & 42.87000 \\
\hline Konsentrasi $(\mathrm{g} / \mathrm{L})$ & 21.38000 & 46.50262 & 98.62000 \\
\hline Waktu (min) & &
\end{tabular}

Parameter optimasi kadar vitamin C minimum terhadap suhu, konsentrasi, dan waktu ditentukan dengan critical value (nilai kritis). Sehingga, nilai kritis untuk optimasi kadar vitamin C minimum dicapai saat suhu $44,96{ }^{\circ} \mathrm{C}$ dengan konsentrasi $18,93 \mathrm{~g} / \mathrm{L}$ selama 46,50 menit.

\section{KESIMPULAN}

Nilai koefisien determinasi $\left(\mathrm{R}^{2}=0,73277\right)$ menunjukkan bahwa $73,27 \%$ dari variabilitas dalam respon dapat dijelaskan oleh model. Model regresi menunjukkan bahwa model ini sangat signifikan, seperti terbukti dari nilai $\mathrm{F}$ dari tes Fisher $($ Fmodel $=24,969)$. nilai optimasi kadar vitamin $\mathrm{C}$ minimum dicapai saat suhu $44,96{ }^{\circ} \mathrm{C}$ dengan konsentrasi $18,93 \mathrm{~g} / \mathrm{L}$ selama waktu evaporasi 46,50 menit.

\section{DAFTAR PUSTAKA}

Permatasari, (2014), Buah nanas, Eprints Politeknik Negeri Sriwijaya. 
Cassano, A., Conidi, C., Timpone, R., D'Avella, M., Drioli, E., (2007), A membrane-based process for the clarification and the concentration of the cactus pear juice, J. Food Eng. 80, $914 \mathrm{e} 921$.

http://dx.doi.org/10.1016/j.jfoodeng.2006 .08 .005 .

Cassano, A., Drioli, E., Galaverna, G., Marchelli, R., Di Silvestro, G., Cagnasso, P., (2003), Clarification and concentration of citrus and carrot juices by integrated membrane processes, J. Food Eng 57, 153e163.

Gaily, M.H.M., (1999), Design, Construction and Performance of an Ohmic Fruit Juice Evaporator, Degree of Master of Science in the Faculty of Engineering University Putra Malaysia.

J. Safitri, (2015), Klasifikasi Tanaman Nanas, Universitas Islam Negeri Sultan Syarif Kasim.

Onsekizoglu, P., (2013), Production of high quality clarified pomegranate juice concentrate by membrane processes. $J$. Memb. Sci. 442, 264e271. http:// dx.doi.org/10.1016/j.memsci.2013.03.061

Onsekizoglu, P., Bahceci, K.S., Acar, M.J., (2010), Clarification and the concentration of apple juice using membrane processes: a comparative quality assessment, $J$. Memb. Sci. 352, 160e165.

Ramteke, R.S., Singh, N.I., Rekha, M.N., Eipeson, W.E., (1993), Methods for concen- tration of fruit Juices: a critical evaluation, J. Food Sci. Technol. 30 (6), $391 \mathrm{e} 402$.

Rocky, (2009), Panen dan Pasca Panen Nanas.

Serdal Sabanci., Filiz Icier, (2017), Applicability of ohmic heating assisted vacuum evaporation for concentration of sour cherry juice, Journal of Food Engineering, 212 (2017) 262e270

Wang, W.C., Chu, C.Y., (2003), Study of vacuum evaporation by using ohmic heating. In: 2003 IFT Annual Meeting Book of Abstracts, Institute of Food Technologists, Chicago, Paper 92B-59. 